\title{
Yield and quality of carrots when using the Gumiton organo-mineral complex in conditions of radioactive contamination
}

\author{
${ }^{1}$ Ratnikov A. N., ${ }^{2}$ Sviridenko D. G., ${ }^{3}$ Petrov K. V., ${ }^{4}$ Ivankin N. G., ${ }^{5}$ Suslov A. A., \\ ${ }^{6}$ Arysheva S. P., ${ }^{7}$ Balanova O. Y., ${ }^{8}$ Mazurov V.N., ${ }^{9}$ Semeshkina P.S., ${ }^{10}$ Filatov A.N.
}

${ }^{1}$ Doctor of biological sciences, professor, leading researcher, ORCID-0000-0001-7298-887X.

${ }^{2} \mathrm{PhD}$ of biological sciences, senior Research. ORCID-0000-0002-7701-895X.

${ }^{3}$ Research, ORCID-0000-0003-4416-6128.

${ }^{4}$ Research, ORCID-0000-0001-6498-8458.

${ }^{5} \mathrm{PhD}$ of Agricultural Sciences, ORCID-0000-0002-7214-5001.

${ }^{6} \mathrm{PhD}$ of biological sciences, senior Research, ORCID-0000-0002-7243-4145.

${ }^{6}$ Research, ORCID-0000-0002-0509-4726.

Russian Institute of Radiology and Agroecology (RIRAE), 249020, Kaluga region, Obninsk, Kievskoe shosse, 109 km, Russia.

${ }^{8} \mathrm{PhD}$ of Agricultural Sciences, Director. ORCID-0000-0003-3427-0116.

${ }^{9} \mathrm{PhD}$ of Agricultural Sciences, deputy director. ORCID-0000-0001-8450-7105,

${ }^{10} \mathrm{PhD}$ of Agricultural Sciences, senior Research. ORCID-0000-0002-9441-5834.

${ }^{9}$ polina.semeshkina@gmail.com

Article History: Received: 11 January 2021; Accepted: 27 February 2021; Published online: 5 April 2021

\begin{abstract}
The aim of this work is to assess the impact of Gumiton peat-based organo-mineral complex on the productivity and quality of carrots and the transition of $137 \mathrm{Cs}$ from soil to root crops under conditions of radioactive contamination. According to the results of field experiments on gray forest and soddy-podzolic soils of the Kaluga region of Russia, it is shown that leaf treatment with Gumiton of carrot plantings in different phases of crop development increases the yield of root crops by $20-40 \%$, depending on the variety, soil type and agricultural background. Analysis of studies in the growing experiment on soddy-podzolic soil showed that Gumiton treatment increases the yield of carrots by $30 \%$. The rate of decrease of $137 \mathrm{Cs}$ content is 1,2-1,25 times. Gumiton is a highly effective preparation for carrots, which increases the productivity and quality of the crop and helps to reduce the intake of 137Cs in root crops in radioactively contaminated areas.
\end{abstract}

Keywords: soil, carrots, Gumiton, root crop, quality, nitrates, ${ }^{137} \mathrm{Cs}$, admission.

\section{INTRODUCTION}

In Russian Federation, the territory of 21 regions was exposed to radioactive contamination after Chernobyl accident in $1986 \mathrm{y}$. The highest levels of pollution were registered in Bryansk, Kaluga, Oryol and Tula regions [1]. As a result of Chernobyl accident, the southern part of the Kaluga region of the Russian Federation was also contaminated, including with long-lived and biologically active radionuclides ${ }^{137} \mathrm{Cs}$ and ${ }^{90} \mathrm{Sr}$. [2]. Most ${ }^{137} \mathrm{Cs}$ enters vegetable crops from soddy-podzolic soils of light granulometric composition, the lowest absorption is characteristic of soddy-podzolic medium-and heavy-loamy, as well as from gray forest soils and chernozems. Based on the obtained coefficients of transfer ${ }^{137} \mathrm{Cs}$ [3] from the soil to the commercial part of the crop, vegetable crops can be arranged in the following descending order: white cabbage $>$ table carrots $>$ table beets [4].

Carrots is one of the most important vegetable crops. It is rich in carotene (provitamin A) - up to 11 and more $\mathrm{mg} \%$, vitamins PP - up to $0.4 \mathrm{mg} \%$, group B: B6 - up to $0.12 \mathrm{mg} \%$, B2 - up to $0.06 \mathrm{mg} \%$, vitamin C, folic acid, essential oil, carbohydrates and mineral salts containing a lot of $\mathrm{Ca}, \mathrm{Na}, \mathrm{B}$, as well as $\mathrm{Fe}, \mathrm{P}, \mathrm{Mg}$ and other elements. The most valuable is considered to be $\beta$-carotene (it is more in red root vegetables), since it is 2 times more active than the $\alpha$ - and $\gamma$-isomers as a precursor of vitamin A [5, 6].

The improvement of the technology of cultivation of agricultural crops, including vegetables, with the use of new types of organic-mineral fertilizers and peat-based complexes developed at RIRAE has been carried out since 2006.

The humic substances contained in peat go into the active state and effectively affect the soil and plants after activation. Activators can be alkalis, mineral compounds, elevated temperatures. This technique is actively used in the production of humic preparations. The use of humic preparations and organo-mineral complexes based on peat is promising and in demand in the agro-industrial sector.

As a result, the use of humic preparations activates growth processes in plants (stimulating effect), increases the resistance of plants to adverse environmental factors and to phytopathogenic microorganisms (adaptagenic and bioprotective effects) [7].

Innovative development of Russian scientists RIRAE is a highly effective organo-mineral complex based on peat Gumiton. There are: patent for invention No. 2709737 of 19.12.2019; Certificate for trademark (service mark) No. 718667 of 05.07.2019. Gumiton is a complex universal liquid concentrate of dark color. A distinctive 
component of Gumiton from its counterparts is the high content of potassium humates - 11-14\%. It consists of: $\mathrm{N}-12 \%, \mathrm{P}_{2} \mathrm{O}_{5}-23 \%, \mathrm{~K}_{2} \mathrm{O}-30 \%$, trace elements (B-0.2, Mo-0.1, Mn-0.1\%), ash residue containing oxides and salts of $\mathrm{Ca}, \mathrm{Mg}, \mathrm{Fe}-14.6 \%$. For the production of Gumiton, lowland peat with a $\mathrm{pH}$ of at least 5.0 , an ash content of $11-13 \%$, and a potassium humates content of $35-45 \%$ are used.

Action Gumiton is based on activating biochemical processes in plants. The use of the complex increases the immunity of plants, increases the efficiency of root nutrition of plants, resulting in increased crop yields and product quality.

Comparison with Russian and foreign analogues (humic fertilizer EDAGUM®SM, liquid preparation Gumistim, complex humic fertilizers Tellura-M and Phoenix, liquid organo-mineral fertilizer STIMULIFE, dry peat-humic fertilizer "FLORA-S", etc., humatized mineral fertilizers) indicates a clear superiority of Gumiton in terms of the amount of humus substances, nitrogen, mobile phosphorus, exchange potassium. One of the key features of Gumiton is the universality of its application (for all agricultural crops, in farms of all forms of ownership, starting from personal subsidiary plots and ending with large agricultural holdings).

Gumiton is used for foliar treatment of vegetating plants by spraying and seed treatment. It is odorless, harmless when used, highly soluble in water, compatible with most used mineral fertilizers and plant protection products. Because of the explicit anti-stress actions on the environmental factors the treatment Gumiton should not be combined with use of herbicides. The optimal duration of treatment of crops with Gumiton to 7 days before or 7 days after herbicide application.

When surface, leaf treatment of plants, the drug is applied in a dose of 1 liter of concentrate per hectare in 300 liters of water (dilution in a smaller volume of water is allowed, which is provided for by the technical characteristics of the sprayer). Treatment of plants with Gumiton is carried out 1-2 times during the growing season, in the responsible phases of plant development (active growth and nutrient consumption) $[8,9,10]$.

\section{MATERALS AND METHODS}

Evaluation of the action of Gumiton on yield and quality of two carrot cultivars was conducted in pots and field experiments on soddy-podzolic and gray forest soils of Kaluga region.

1). On the gray forest medium loamy soil on the basis of "Mayak" of Peremyshl district, Kaluga region.

Agrochemical characteristics of the soil: humus content $-2.1 \% ; \mathrm{pH}_{\mathrm{KCl}} 6.66 ; \mathrm{Ca}$ and $\mathrm{Mg}$ content-13.8 and 3.9 $\mathrm{cmol}$ (eq)/100 $\mathrm{g}$ of soil; exchangeable potassium and mobile phosphorus - 275 and $268 \mathrm{mg} / \mathrm{kg}$ of soil, respectively. Carrot variety - Chinese beauty. Treatment of plants with Gumiton was carried out in the phase of 4 pairs of real leaves.

2) On gray forest medium loamy soil on the basis of Kaluga research Institute of Agriculture - branch of Federal state budgetary institution "FSBI of potato named after A. G. Lorch». Agrochemical indicators of soil: $\mathrm{pH}_{\mathrm{KCl}}$ 5,6; humus content-2,1\%; total N-12,0\%; $\mathrm{P}_{2} \mathrm{O}_{5}$ and $\mathrm{K}_{2} \mathrm{O}-135$ and $160 \mathrm{mg} / \mathrm{kg}$ of soil, the content of mobile forms of trace elements: $\mathrm{Cu}-4,3 ; \mathrm{Zn}-2,5 ; \mathrm{B}-1,17$; Mo-0,66; Mn-81,4 mg/kg of soil, respectively. Carrot variety Shantane Royal.

Scheme of experience: 1. Technology for agriculture (NPK)- $\mathrm{N}_{60} \mathrm{P}_{60} \mathrm{~K}_{60}$. 2. NPK + treatment with Humicola carrots in the phase of closing leaves.

3) On soddy-podzolic sandy loam soil on the basis of RIRAE. Carrot variety Shantane Royal. Experience scheme: 1. Control without fertilizer. 2. Control + Gumiton. 3. Complex fertilizer Azofoska (N-16\%; $\mathrm{P}_{2} \mathrm{O}_{5}-16 \%$; $\left.\mathrm{K}_{2} \mathrm{O}-16 \%\right), \mathrm{N}_{60} \mathrm{P}_{60} \mathrm{~K}_{60}$;. 4. Azofoska + Gumiton. Treatment of vegetative carrot plants with Gumiton was carried out in the phase of 4 pairs of real leaves.

4). In the conditions of a pots experiment on soddy-podzolic sandy loam soil on the basis of RIRAE studied the effect of ${ }^{137} \mathrm{Cs}$, azofoska and Gumiton on the productivity of carrot variety of Shantane Royal, the quality of the crop and intake of ${ }^{137} \mathrm{Cs}$ to plants from contaminated soil. Agrochemical indicators of soil: $\mathrm{pH}_{\mathrm{KCl}} 4.7$; hydrolytic acidity-4.12 cmol (eq)/100 g of soil; humus content-1.2\%; content of mobile phosphorus and exchangeable potassium-124 and $135 \mathrm{mg} / \mathrm{kg}$ of soil, $\mathrm{Ca}$ and $\mathrm{Mg}-1.17$ and $0.21 \mathrm{~cm}$ (EQ)/100 $\mathrm{g}$ of soil, respectively; the sum of absorbed bases $-1.80 \mathrm{~cm}(\mathrm{EQ}) / 100 \mathrm{~g}$ of soil.

Scheme of experience: 1. Soil without fertilizers $+{ }^{137}$ Cs. $2 . \mathrm{N}_{0.15} \mathrm{P}_{0.15} \mathrm{~K}_{0.15} \mathrm{~g} / \mathrm{kg}$ of soil (NPK) $+{ }^{137} \mathrm{Cs} .3$. Azofoska $+{ }^{137}$ Cs. 4. Soil without fertilizers $+{ }^{137} \mathrm{Cs}+$ processing Gumiton; 5. NPK $+{ }^{137} \mathrm{Cs}+$ processing Gumiton; 8. Azofoska $+{ }^{137} \mathrm{Cs}+$ processing Gumiton. The radionuclide was introduced as a solution of ${ }^{137} \mathrm{Cs}$ chloride in the amount of $74 \mathrm{kBq} / \mathrm{kg}$ of soil. NPK was introduced into the soil in the form of solutions of salts $\mathrm{NH}_{4} \mathrm{NO}_{3}, \mathrm{KH}_{2} \mathrm{PO}_{4}, \mathrm{~K}_{2} \mathrm{SO}_{4}\left(\mathrm{~N}_{150} \mathrm{P}_{150} \mathrm{~K}_{150} \mathrm{mg} / \mathrm{kg}\right)$. Vessel contained $6 \mathrm{~kg}$ of soil. The repetition is 4 times. 15 seeds were sown in each vessel, and 5 plants were left after the emergence of seedlings. Treatment of carrots with Gumiton were conducted twice: in the phase of forming of root crop and 3 weeks after the first treatment.

Planning of the growing experience, analysis of the structure of the crop after harvesting carrots was carried out according to Zhurbitsky Z. I. [11]. Planning of field experiments and analysis of the structure of the crop was carried out according to Dospekhov B. A. [12]. 
The content of ${ }^{137} \mathrm{Cs}$ in root crops was measured by semiconductor gamma-ray spectrometry using an ultrapure germanium detector (HPGe, ORTEC) and an IN 1200 spectrum analyzer (INTERTECHNIQUE), France. The determination of nitrates was carried out by a SOEX Nitrate tester, model: NUK-019-1.

Statistical data processing was performed using the Microsoft Excel 2007 program with a 95\% level of significance of the results.

\section{RESULTS AND DISCUSSION}

According to the data of researchers who studied the accumulation of ${ }^{137} \mathrm{Cs}$ in the crop yield on the soddypodzolic sandy loam soil of Polesie of Ukraine, it was found that among vegetable crops the values of transfer coefficient of ${ }^{137} \mathrm{Cs}-\mathrm{CT}^{137} \mathrm{Cs}(\mathrm{Bq} / \mathrm{kg}$ of root crops $) / \mathrm{kBq} / \mathrm{m}^{2}$ in soil) in carrots, dill, parsnips, potatoes, Jerusalem artichoke, radishes are 0.1-0.2 [13]. According to the accumulation of ${ }^{137} \mathrm{Cs}$, carrot varieties differ by 2.5 times [14]. "Potassium" therapy of radionuclide-contaminated lands was used in a timely manner by Belarusian agrochemists and soil scientists together with the "Belaruskali" enterprise to decontaminate soils and produce environmentally safe products after Chernobyl accident. Within five years, the experience gained in the farms of Republic of Belarus in the implementation of increased doses of potash fertilizers (up to N200 kg of active substance per $1 \mathrm{ha}$ ) allowed to reduce the accumulation of caesium-137 in fodder root crops by 2.7 times [15].

When studying samples of table carrots, it was noted that patterns in the accumulation of radionuclides in various parts of the root crop did not appear. The level of accumulation of ${ }^{137} \mathrm{Cs}$ in different varieties (Bordo 237, Neghnost, Nantskaya, Marlinka) did not coincide and differed in elements. The maximum content of ${ }^{137}$ Cs was found in the upper part of the root crop of the Marlinka variety. Only for this variety, the upper part of the phloem is more polluted. In the tissue of xylem root crops, the lowest content of ${ }^{137} \mathrm{Cs}$ was observed in the upper part [16].

Shantane carrot variety is medium-ripe, high-yielding, common in the Central region of Russian Federation. The period from sowing to harvesting of root crops is 108-125 days. The root crop has a length of up to $20 \mathrm{~cm}$, the flesh is orange, the taste qualities are average, resistant to diseases, the keeping quality is good [17].

The results of the application of Gumiton on carrot variety Chinese beauty in Peremyshl district, Kaluga region on the gray forest medium loamy soil it was found that a single spraying of planting Gumiton on phase of 4 pairs of true leaves contributed to the growth of crop roots from 20 to $23.9 \mathrm{t} / \mathrm{ha}$ or $19.5 \%$, compared to the control.

In a field experiment on gray forest medium loamy soil on the basis of Kaluga scientific research Institute of Agriculture - branch of Federal state budgetary institution "FSBI of potato named after A. G. Lorch», it was shown that a single treatment of carrot plantings of the Shantane Royal variety with Gumiton during the leaf closing phase increased the crop yield from 31.6 to $40.1 \mathrm{t} / \mathrm{ha}$, or by $26.9 \%$ compared to the control.

According to the results of a field experiment on the basis of RIRAE on soddy-podzolic sandy loam soil, the introduction of azofoska contributed to an increase in carrot yield by $4.3 \mathrm{t} /$ ha or $20.5 \%$ compared to the control (without fertilizers). Treatment plant Gumiton in the phase of closing leaves caused increase of root yield of 5.0 $\mathrm{t} / \mathrm{ha}$, or by $23.8 \%$ in the control and $10.7 \mathrm{t} / \mathrm{ha}$ or $42.3 \%$, when introduced into the soil azofoska, respectively (table. 1). Compared with the control without fertilizer the productivity of carrots when you make azofoska and processing Gumiton increased by 15.0 t/ha or $71,4 \%$.

Table 1. Yield of carrot root crops, $t /$ ha when using azofoska and leaf treatment with the organo-mineral complex Gumiton. Field experience RIRAE. 2020

\begin{tabular}{|l|l|l|}
\hline Variant & Yield of root crops, $\mathrm{t} /$ ha & $\begin{array}{l}\text { Yield increase in the processing } \\
\text { Gumiton, } \mathrm{t} / \mathrm{ha}(\%)\end{array}$ \\
\hline Control - without fertilizers & 21,0 & - \\
\hline Control + Gumiton & 26,0 & $5,0(23,8 \%)$ \\
\hline Azofoska $\left(\mathrm{N}_{60} \mathrm{P}_{60} \mathrm{~K}_{60}\right)$ & 25,3 & - \\
\hline Azofoska + Gumiton & 36,0 & $10,7(42,3 \%)$ \\
\hline LSD $_{05}$ & 2,5 & - \\
\hline
\end{tabular}

The results of studies in the vegetation experiment based on RIARAE on soddy-podzolic sandy loam soil containing ${ }^{137} \mathrm{Cs}$ showed that the introduction of NPK in the form of salt solutions increased the mass of root crops by $91 \%$ compared to the control (table 2 ).

Double application of Gumiton on carrot plantings contributed to an increase in the yield of root crops by $30 \%$ in the variant with azofoska compared to the variant without spraying.

Table 2. Effect of various types of fertilizers and Gumiton on the productivity of carrots of the Chantene Royal variety on soddy-podzolic sandy loam soil containing ${ }^{137} \mathrm{Cs}$. Vegetation experience

\begin{tabular}{|l|l|}
\hline Variant & Weight of root crops, g/vessel \\
\hline Soil without fertilizers $+{ }^{137} \mathrm{Cs}$ - control & 88,5 \\
\hline
\end{tabular}


Ratnikov A. N., Sviridenko D. G., Petrov K. V., Ivankin N. G., Suslov A. A., Arysheva S. P., Balanova O. Y., Mazurov V.N., Semeshkina P.S., Filatov A.N.

\begin{tabular}{|l|l|}
\hline Control + Gumiton & 94,1 \\
\hline NPK $+{ }^{137} \mathrm{Cs}$ & 169,0 \\
\hline NPK $+{ }^{137} \mathrm{Cs}+$ Gumiton & 153,9 \\
\hline NPK + azofoska $+{ }^{137} \mathrm{Cs}$ & 120,8 \\
\hline NPK + azofoska $+{ }^{137} \mathrm{Cs}+$ Gumiton & 156,7 \\
\hline LSD $_{05}$ & 14,2 \\
\hline
\end{tabular}

According to Sanitary rules and regulations SRR 2.3.2. $2650-10$, the permissible level of ${ }^{137} \mathrm{Cs}$ content in vegetables is $80 \mathrm{~Bq} / \mathrm{kg}$ [18]. The content of ${ }^{137} \mathrm{Cs}$ in root crops decreased by 5.9 and 2.4 times compared to the control with the introduction of NPK and azofoska, respectively. The use of Gumiton on the NPK background reduced the activity of ${ }^{137} \mathrm{Cs}$ in carrot root crops by 1.25 times, and on the azofoska background-by 1.2 times compared to the untreated variant, respectively (table. 3) [19]. The decrease of ${ }^{137} \mathrm{Cs}$ transfer in the roots when treated with Gumiton is due to the effect of "dilution" with the increased yield. Despite the decrease in the accumulation of ${ }^{137} \mathrm{Cs}$ in root crops, the radionuclide content in carrots remains 13-99 times higher than the existing standards.

Table 3. Effect of various types of fertilizers and Gumiton on the content of ${ }^{137} \mathrm{Cs}$ in carrot root crops on soddypodzolic sandy loam soil. Vegetation experience 2018

\begin{tabular}{|l|l|}
\hline Variant & ${ }^{137} \mathrm{Cs}$ content in carrot roots, $\mathrm{Bq} / \mathrm{g}$ \\
\hline Soil without fertilizers $+{ }^{137} \mathrm{Cs}-$ control & 7791 \\
\hline Control + Gumiton & 7958 \\
\hline NPK $+{ }^{137} \mathrm{Cs}$ & 1313 \\
\hline NPK $+{ }^{137} \mathrm{Cs}+$ Gumiton & 1053 \\
\hline NPK + azofoska $+{ }^{137} \mathrm{Cs}$ & 3288 \\
\hline NPK + azofoska $+{ }^{137} \mathrm{Cs}+$ Gumiton & 2742 \\
\hline LSD $_{05}$ & 188 \\
\hline
\end{tabular}

\section{CONCLUSIONS}

1. According to the results of field experiments on gray forest soils in farms of various forms of ownership of the Kaluga region of Russia, a single leaf treatment of carrot plantings of various varieties with Gumiton organomineral complex in various phases of plant vegetation contributes to an increase in crop yield by $20-27 \%$ in relation to the control.

2. In a field experiment on soddy-podzolic sandy loam soil it was shown that single treatment of planting carrots variety of Shantane Royal Gumiton in the phase of closing leaves increases the yield of root crops in 24-42\%, depending on soil fertility, in comparison with variants without spraying complex.

3. The results of studies in the growing experiment on soddy-podzolic soil with carrots of the same variety showed that double treatment of plantings with Gumiton increases the yield by $30 \%$. The multiplicity of reducing the transition of ${ }^{137} \mathrm{Cs}$ to root crops when using Gumiton is 1.2-1.25 times.

4. Gumiton is a highly effective preparation in carrot growing technologies, used to increase the productivity and quality of the crop and reduce the intake of ${ }^{137} \mathrm{Cs}$ in root crops on radioactively contaminated soils.

\section{REFERENCES}

1. Agroecology. Edited by V. A. Chernikov and A. I. Chekeres. Moscow: Kolos, 2000. 536 p.

2. Alexakhin R. M. Scientific bases of agricultural production in technogenically polluted territories, ensuring the production of products that meet the standards. Obninsk. - 2004. - $110 \mathrm{p}$.

3. Agricultural radioecology / Alexakhin R. M., Vasiliev A.V., Dikarev V. G. et al.; Edited by Alexakhin R. M., Korneev N. A. M.: Ecology, 1992, 400 p. ISBN 5-7120-0684-7.

4. Belt E. L., Stepanenko O. S., Kuzmicky A. N. Accumulation of ${ }^{137} \mathrm{Cs}$ in vegetable crops on sodpodzolic sandy loam soil // Soil, crop and environment: proceedings of the XI International scientific conference of students and undergraduates "Scientific search of youth of XXI century", dedicated to the 170th anniversary of the Belarusian state agricultural Academy.: Belarusian state agricultural Academy, Gorki, 2010. P. 179-180.

5. Tarasenko V. I., Your garden. Smolensk: Rusich, 1998. 576 p.

6. Chernikov V. A., Sokolov O. A. Environmentally safe products. Moscow: Kolos, 2009. P. 85-86.

7. Motovilova JI. B., Berman O. N., Skvortsov O. V. Humates-environmentally friendly stimulators of plant growth and development. // Chemistry in agriculture,1999. No. 5. P. 12-13.

8. Ratnikov A. N., Sviridenko D. G., Arysheva S. P., Semoshkina P. S. Effect of new organo-mineral complex GUMITON on the productivity and quality of cereals on different soil types // Agrarian Bulletin of the Urals, No. 4 (195) 2020 P. 29-37. DOI: 10.32417/1997-4868-2020-195-4-29-37. 
9. Ratnikov A. N., Sviridenko D. G., Arysheva S. P., Petrov K. V., Ivankin N. G., Suslov A. A., Semeshkina P. S. Assessment of the use of organomineral complex Gumiton: in spring cereals // Agrochemical Bulletin, № 4 2020. P. 21-24. DOI: 10.24411/1029-2551-2020-10050.

10. Suslov A. A., Ratnikov A. N., Sviridenko D. G., Aryshev S. P., Ivankin N. G., Petrov V. K., Mamaev V. V., Torikov V. E. Organomineral complex Gumiton as an element of adaptive technology of winter wheat cultivation in the Bryansk region // Agrochemical Bulletin, No. 4 2020. P. 24-29. DOI: 10.24411/1029-2551-2020-10051.

11. Zhurbitsky Z. I. Theory and practice of vegetative experience. Moscow: Nauka, 1968. 266 p.

12. Dospekhov B. A. Methodology of field experience / B.A. Dospekhov. Moscow: Kolos, 1985. 336 p.

13. Bondar P. F., Loshilov N. A., Tereshchenko N. R., Maslo A. V. Accumulation of caesium-137 in the crop yield on sod-podzolic sandy loam soil of Polesie of Ukraine // Agrochemistry, 1994. No. 5. P. 7479.

14. Khandogina E. K., Barkhudarov R. M. et al. About radiation popular. Moscow: Komtekhprint, 2006. 48 p.

15. Zhigareva T. L., Ratnikov A. N., Popova G. I., Sanzharova N. I., Petrov K. V., Belous N. M. Efficiency of mineral fertilizers in radioactively contaminated territories. // Chemistry in agriculture, 1996. No. 1. P. 35-37.

16. Soldatenko A.V., Pivovarov V. F., Dobrutskaya E. G. Features of accumulation of radionuclides in various food organs of vegetable crops // Vegetables of Russia. No. 3 (28), 2015. P. 39-43.

17. https://fermer.blog/bok/ogorod/morkov/sorta-morkovi/srednie-sorta-morkovi/4634-morkovshantane.html.

18. Hygienic requirements for the safety and nutritional value of food products. Sanitary and epidemiological rules and regulations. SRR 2.3.2.1078-01, SRR 2.3.2.2650-10.

19. Ratnikov A. N., Arysheva S. P., Popova G. I., Balanova O. Y., Sviridenko D. G., Suslov A. A., Petrov K. V., Ivankin N. G., Ratnikova L. I., Semeshkina P. S. Effectiveness of complex fertilizer of prolonged action of SUPRODIT-M and organo-mineral complex GUMITON in carrot cultivation under conditions of radioactive contamination // Bulletin of agrarian science, 1 (76), February 2019. Pp. 44-51. http://dx.doi.org/ro.rs2r7/4g4g4. 